\title{
Analysis of Online Learning System Needs Based on MOOCs
}

\author{
Fitri Masito', Eko Risdianto², I Gusti Agung Ayu Mas Oka3, Yanti Daryanti4, \\ Irwan Fathurrochman5
}

DOI: 10.35445/alishlah.v13i2. 670

\begin{tabular}{ll}
\hline Article Info & Abstract \\
Keywords: & This study aims to analyze the needs of an online learning system based on \\
MOOCs; & MOOCs at Poltekbang Palembang. This type of research is survey research \\
Online; & which can later become the basis for further development research. The \\
Needs Analysis & research instrument used was a needs analysis questionnaire with 21 questions \\
& given to 115 respondents who were students of the Palembang Poltekbang. In \\
& this study, data analysis used descriptive statistics. Based on the results of the \\
& data obtained, it can be concluded that currently, students need an online \\
& learning system based on MOOCs. It is based on the data obtained from all \\
& statements regarding the needs of Palembang Poltekbang students for effective \\
& online learning. Almost all of them were answered, with the most significant \\
percentage being in the answer choices strongly agree and agree. Students need \\
the points offered in each statement that they fill out on the needs questionnaire \\
sheet. The Va value of 3.4339 was also obtained from the data obtained, which \\
entered the valid category. While the reliability value obtained is o.91, and the \\
value is greater than $\mathrm{r}_{\text {table }}$ for df $=113$, which is o.1832 because $\mathrm{r}_{\text {count }}>\mathrm{r}_{\text {table, then }}$ \\
it is included in the reliable category.
\end{tabular}

Keywords:

MOOCs;

Online;

Needs Analysis

\begin{abstract}
Penelitian ini bertujuan untuk melakukan analisis kebutuhan sistem pembelajaran daring berbasiskan MOOCs di Poltekbang Palembang. Jenis penelitian ini merupakan penelitian survei yang nantinya bisa menjadi dasar dalam penelitian pengembangan selanjutnya. Instrumen penelitian yang digunakan berupa angket analisis kebutuhan dengan 21 butir pertanyaan yang diberikan kepada 115 responden yang merupakan mahasiswa Poltekbang Palembang. Dalam penelitian ini analisis data menggunakan statistik deskripsi. Berdasarkan hasil data yang diperoleh dapat disimpulkan bahwa saat ini mahasiswa sangat membutuhkan sistem pembelajaran daring berbasiskan MOOCs. Hal ini didasarkan pada data yang diperoleh bahwa dari seluruh pernyataan mengenai kebutuhan mahasiswa Poltekbang Palembang tehadap pembelajaran daring yang efektif, hampir semuanya dijawab dengan persentase terbesar berada pada pilihan jawaban sangat setuju dan setuju. Ini berarti bahwa mahasiswa membutuhkan poin-poin yang ditawarkan pada setiap
\end{abstract}

\footnotetext{
${ }^{1}$ Politeknik Penerbangan Palembang, Indonesia

Email : fitri.masito@poltekbangplg.ac.id

2 Universitas Bengkulu, Indonesia

Email: eko.risdianto@unib.ac.id

3 Politeknik Penerbangan Palembang, Indonesia

Email : igusti.agungayu @poltekbangplg.ac.id

4 Politeknik Penerbangan Palembang, Indonesia

Email : yantidaryanti@poltekbangplg.ac.id

5 Institut Agama Islam Negeri (IAIN) Curup, Indonesia

Email: irwan@iaincurup.ac.id
} 


\begin{abstract}
pernyataan yang mereka isi pada lembar angket kebutuhan. Dari data yang diperoleh juga didapatkan nilai nilai Va sebesar 3,4339 yang masuk ke kategori valid. Sedangkan nilai reliabilitas diperoleh sebesar 0,91, dan nilai tersebut lebih besar dari $r$ tabel untuk $\mathrm{df}=113$ yaitu sebesar 0,1832 , karena $\mathrm{r}_{\text {hitung }}>\mathrm{r}_{\text {tabel }}$ maka masuk ke kategori reliabel.
\end{abstract}

\title{
INTRODUCTION
}

The development of digital technology in the current Industry 4.0 era has brought changes and influenced various aspects of human life, including education (Putrawangsa \& Hasanah, 2018). The history of the industrial revolution 4.0 cannot be separated from the previous stages of the industrial revolution. The industrial revolution started from 1) Industrial Revolution 1.0 occurred in the 18th century through the invention of the steam engine, thus allowing goods to be massproduced, 2) Industrial Revolution 2.0 occurred in the 19-20th century through the use of electricity which made production costs cheap, 3 ) The Industrial Revolution 3.0 occurred around the 1970s through the use of computers, and 4) The Industrial Revolution 4.0 itself occurred around the 2010 s through intelligence engineering and the internet of things as the backbone of the movement and connectivity of humans and machines (Risdianto, 2019). So the number four in the term industrial revolution 4.0 refers to the fourth revolution(Prasetyo \& Sutopo, 2018). Making Indonesia 4.0 is an integrated roadmap to implement several strategies in entering the Industry 4.0 era. Ngakan Timur Antara (2019) emphasized that all institutions that produce human resources, including general and vocational education, must change the paradigm of thinking in providing education (Wardina et al., 2019).

Along with technology development, teaching and learning in the era of the industrial revolution 4.0 are also changing. The internet and computers are tools that will facilitate the teaching and learning process. The learning process that used to be done face-to-face directly between teachers and students, now in the industrial revolution 4.0 era learning can be done with online classes through social media or other media that support the online learning process. (Nastiti \& Abdu, 2020). The internet network has entered remote areas so that those in the village can also obtain what can be accessed in the city so that it does not become an obstacle to doing online learning(Sabri, 2019).

Online learning is learning "in the network" as a translation of the term online which means connecting to a computer network. Online learning is a fun learning strategy for students (students) because they can listen to it via smartphones, laptops, or computers, not just listening to books.(Argahani, 2020). Online learning utilizes multimedia technology, videos, virtual classes, animated online text, voice messages, email, conference calls, and online video streaming. Learning can be done massively with an unlimited number of participants. It can be done for free or paid.(Jayul \& Irwanto, 2020). Online learning, online, or distance learning, aims to meet educational standards by utilizing information technology by using computers or gadgets that are interconnected with students and teachers as well as students with lecturers(Dyah Purnama Sari \& Sutapa, 2020). With online learning, students have the flexibility of learning time, can study anytime and anywhere. Students can interact with teachers using several applications such as classroom, video conference, telephone or live chat, zoom, or WhatsApp group(Goddess, 2020).

MOOCs are present as a new model of education and learning, which uses the internet to deliver lecture materials at the world's prestigious universities and educational institutions, creating a kind of revolution. These people are joining together to conduct sustainable courses (Risdianto et al., 2021). In Indonesia, there are currently many MOOCs offered by various universities with various methods and platforms. Meanwhile, overseas, MOOC developed and was even facilitated by several well-known universities such as Harvard, Stanford, Oxford, and others (Hardi et al., 2018). Although there are concerns that this can bring disruption and reduce the quality of education in higher education institutions, MOOCs can redefine the concept of higher education by providing new 
learning opportunities for prospective students in faculties and universities to gain the best possible skills (Husna, 2019).
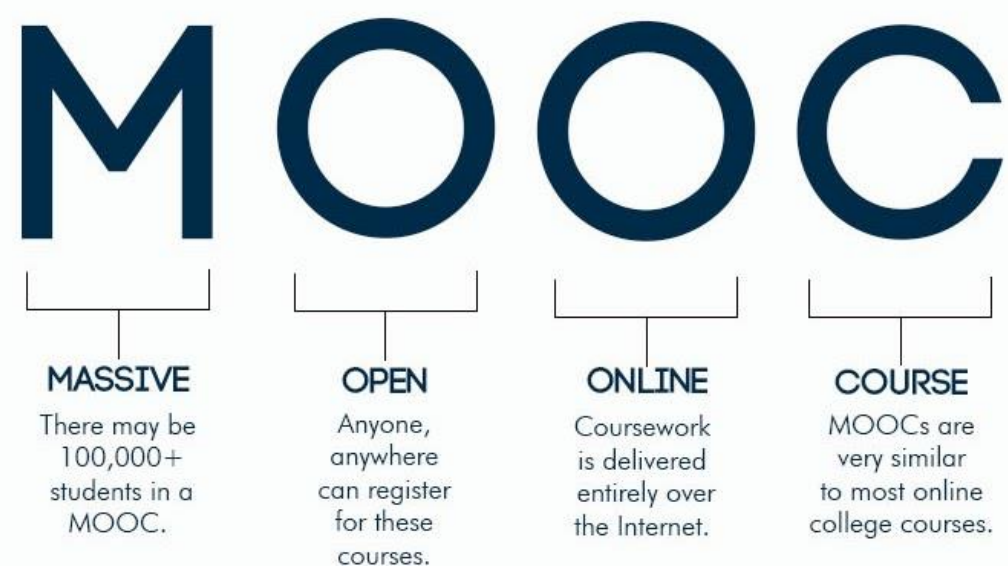

Figure 1. Meaning of MOOC

In principle, MOOCs describe Online Courses with many open registrations (massive), which provide admission administration services and in terms of content, design, access points, application methods, and definition of success. (Emigawaty, 2017). MOOC also uses technology diversification as a technology applied to distance learning, although in a small, traditional, and adaptable scope of things(Praherdhiono et al., 2018). Teachers or lecturers are now encouraged to be proficient in elearning literacy, such as MOOCs, to apply and utilize knowledge in the 21st-century world in the teaching and learning process (Ismail et al., 2018). research similar study about learning with MOOCs has been done by Ismail et al. (2018). The study results show that MOOC learning is very good and can increase students' interest and motivation (Fathurrochman et al., 2021). Another study was also conducted by Eldwita et al. (2019). This study concluded that learning with MOOCs was adequate for use in physics learning (Busri et al., 2019).

Based on the description above, the researcher will research the Need Analysis of Online Learning Systems Based on MOOCs at Poltekbang Palembang, where no previous research has examined this topic at this location.

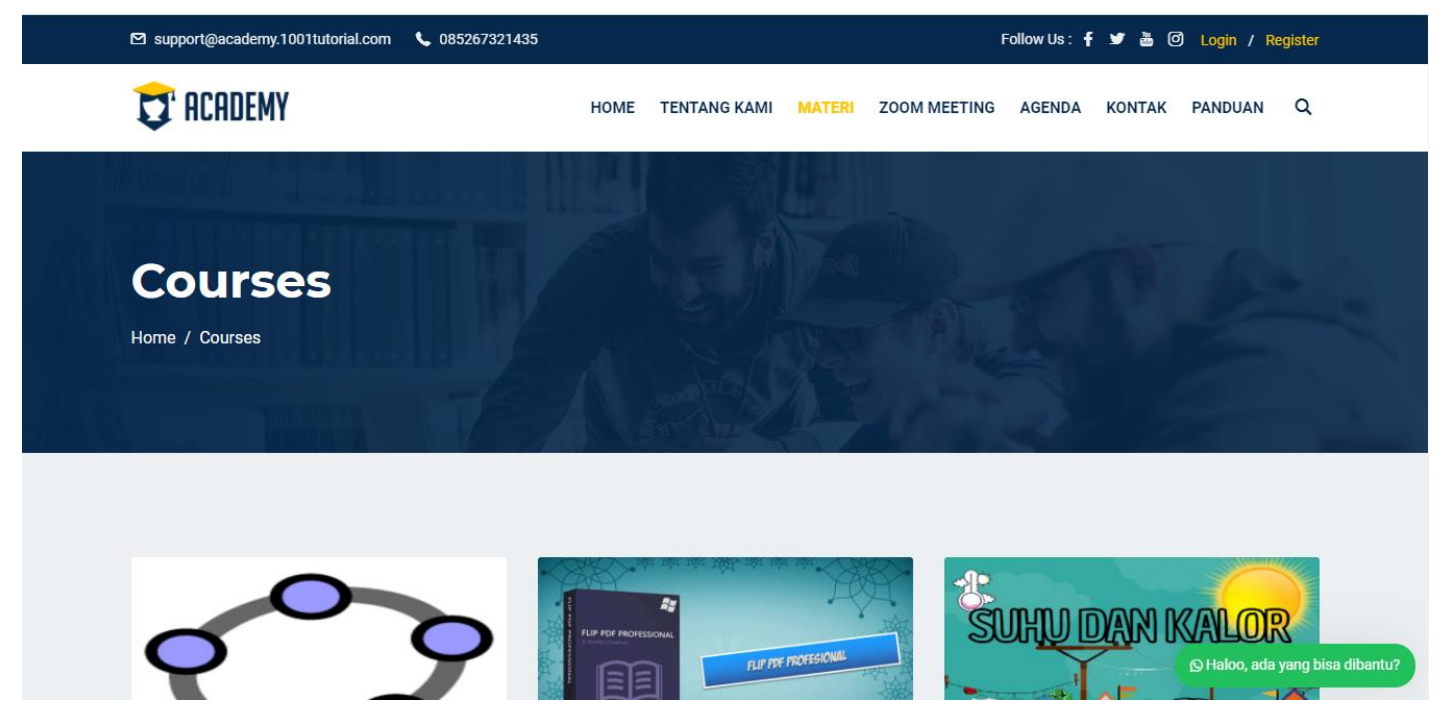

Figure 2. Examples of Display MOOCs Developed By Academy.10o1tutorial.com 


\section{METHODS}

The research was conducted at Poltekbang Palembang in May 2021. The research sample was 115 students from Poltekbang Palembang. The data collection technique used in this needs analysis research is a survey technique. The research instrument used was a questionnaire sheet on the needs of Palembang Polytechnic students for an effective MOOCs learning system consisting of 21 statements. The data analysis technique used is descriptive statistical analysis. Needs analysis is carried out on the data obtained in the form of percentages. The percentage is obtained based on a modified Likert scale calculation. With a Likert scale, the variables to be measured are translated into variable indicators. Furthermore, these indicators are used as guidelines in compiling items in the form of questions or statements.

\section{Table 1. Likert Scale Calculation}

\begin{tabular}{cc}
\hline Rating & Scale Value \\
\hline Strongly agree & 4 \\
Agree & 3 \\
Disagree & 2 \\
Strongly Disagree & $\mathbf{1}$ \\
\hline
\end{tabular}

The questionnaire data was tested for validity and reliability. Valid or not, the data is seen from the resulting Va size, adjusted according to the following interpretation.

To find the magnitude of $\mathrm{Va}$, we can use the formula

$$
V_{a}=\frac{\Sigma_{1}^{3} A_{i}}{n}
$$

Where: $\Sigma_{1}^{3} A_{i}$ is the number of acquisition scores while $\mathrm{n}$ is the number of items.

The Va value that we get is then adjusted according to the following validity interpretation table.

Table 2. Validity Interpretation

\begin{tabular}{cll}
\hline No & The size & Criteria \\
\hline 1 & $1 \leq V_{a}<2$ & Invalid \\
2 & $2 \leq V_{a}<3$ & Less Valid \\
3 & $3 \leq V_{a}<4$ & Valid \\
\hline
\end{tabular}

To find the reliability of the data, we use the formula

$$
\text { R eliabilitas }=\left(\frac{k}{k-1}\right)\left(1-\frac{\Sigma \sigma_{n}}{\sigma_{t}}\right)
$$

Where $\mathrm{k}$ is the number of items, $\Sigma \sigma_{n}$ is the number of item variants and $\sigma_{t}$ is the total variance The data is said to be reliable if rcount $>$ rtable.

\section{FINDINGS AND DISCUSSION}

The needs analysis for online learning based on MOOCs is addressed to Palembang Polytechnic students. This analysis was conducted to determine the teaching and learning system 
expected by Palembang Poltekbang students, especially during the implementation of online learning. The statements presented in the needs questionnaire are structured in such a way by directing them to a MOOCs-based learning system. From these statements, it can be concluded that the level of student needs at Poltekbang Palembang for online learning is based on MOOCs.

On the requirement sheet for an effective online learning system, the following results are obtained

Table 3. Percentage of Results of Filling Out Needs Questionnaire

\begin{tabular}{|c|c|c|c|c|c|}
\hline \multicolumn{2}{|r|}{ Statement } & \multicolumn{4}{|c|}{ Rating } \\
\hline & & $\begin{array}{l}\text { Strongly } \\
\text { Agree }\end{array}$ & Agree & Disagree & $\begin{array}{l}\text { Strongly } \\
\text { Disagree }\end{array}$ \\
\hline 1 & $\begin{array}{l}\text { I like learning that uses electronic devices such as } \\
\text { computers and cellphones }\end{array}$ & $64 \%$ & $33.6 \%$ & $2.4 \%$ & 0 \\
\hline 2 & $\begin{array}{l}\text { I prefer internet-based learning to conventional } \\
\text { learning }\end{array}$ & $35.8 \%$ & $43.3 \%$ & $17.5 \%$ & $3.4 \%$ \\
\hline 3 & I like audio-visual based learning & $35 \cdot 7 \%$ & $47 \%$ & $15.6 \%$ & 1.7 \\
\hline 4 & $\begin{array}{l}\text { I like the explanation of the material in the form of } \\
\text { video tutorials }\end{array}$ & $43 \cdot 3 \%$ & $39.6 \%$ & $14.5 \%$ & $2.6 \%$ \\
\hline 5 & $\begin{array}{l}\text { I like material that can be accessed anytime and } \\
\text { anywhere }\end{array}$ & $78.4 \%$ & $20 \%$ & $1.6 \%$ & 0 \\
\hline 6 & $\begin{array}{l}\text { I am more enthusiastic about studying sequential or } \\
\text { structured material }\end{array}$ & $72.4 \%$ & $26 \%$ & $1.6 \%$ & o \\
\hline 7 & I want learning that can be accessed online & $51.4 \%$ & $41 \%$ & $7.6 \%$ & o \\
\hline 8 & $\begin{array}{l}\text { I prefer learning where I can monitor my own } \\
\text { learning progress }\end{array}$ & $68.1 \%$ & $30.4 \%$ & $1.5 \%$ & o \\
\hline
\end{tabular}

The table above shows that students like learning that use electronic devices such as computers and cellphones. This is seen from the percentage who answered strongly agree as much as $64 \%$ and 33.6\% answered agree, while the rest answered disagree. Students prefer internet-based learning compared to conventional learning, as evidenced by $43.3 \%$ of students answering agree and $35.8 \%$ strongly agree while the rest answered disagree and strongly disagree. In the next item, a statement is given that students like audio-visual-based learning. Here the results are that $47 \%$ of students agree with the statement, and $35.7 \%$ answered strongly agree, while the rest answered disagree and strongly disagree. In addition, students also liked the explanation of the material in video tutorials, with the percentage of students who answered strongly agree as much as $43.3 \%$ and $39.6 \%$ answered agree. In contrast, the rest answered disagree and strongly disagreed. Then students also like material that can be accessed anytime and anywhere, with a percentage of $78.4 \%$ who answered strongly agree.

Furthermore, from the needs questionnaire, $72.4 \%$ answered strongly agree that students are more enthusiastic about learning sequential or structured material. As for the statement that students want learning that can be accessed online, 51.5\% answered strongly agree, and $41 \%$ answered agree. Then $98.5 \%$ of students answered agree and strongly agree that they prefer learning to monitor their progress.

The questionnaire also found that students were more motivated to learn with teaching materials that had animations and learning whose materials could be studied repeatedly. Students also expect learning that can improve students' digital literacy skills by presenting various forms of material such as video tutorials, animations, audio, and others to get learning media that they can use independently. Students also agreed that they needed learning that did not require them to take notes one by one. From the results of the questionnaire, students also stated that they would be more disciplined in doing assignments and evaluations given by the lecturer, would not skip learning activities, would be more honest in taking tests, would be more daring to express opinions, be more daring to ask questions from the lecturer, and not embarrassed to ask friends who understand first if learning is done through a programmed learning system (e-learning, Google Classroom, etc.). 
Of the overall statements in the needs questionnaire, the most significant percentage chosen by students at Poltekbang Palembang is the strongly agree and agree on option. It shows that students at Poltekbang Palembang expect an online learning system that meets the criteria as contained in the statements in the needs questionnaire. Due to the statements presented in the needs questionnaire have been arranged to direct them to a MOOCs-based learning system, it can be concluded that students at Poltekbang Palembang need an online learning system based on MOOCs.

A validity test is carried out to convince or show the feasibility of the statements compiled in the needs questionnaire in measuring the level of student needs at the Palembang Poltekbang for online learning systems based on MOOCs. Then, in measuring the consistency of a series of measurements that have been carried out, a reliability test is carried out. These two tests were carried out using data obtained from the results of questionnaire data that students from the Palembang Poltekbang had filled out. From the data from the needs questionnaire that 115 students from the Palembang Poltekbang have filled out, the Va value is 3.4339 , which is in the valid category. These results indicate that the instrument or questionnaire on the need for an online learning system based on MOOCs is used to obtain data on the level of needs of students at Poltekbang Palembang for an online learning system based on MOOCs is feasible to use. While the reliability value obtained is 0.91 , and the value is greater than $\mathrm{r}$ table for $\mathrm{df}=113$, which is 0.1832 because rcount>rtable, then it is included in the reliable category. These results indicate consistency, meaning that if the developed needs questionnaire is repeated, it will get the same results. This value is greater than $\mathrm{r}$ table for $\mathrm{df}=113$, which is 0.1832 because rcount $>$ rtable is included in the reliable category. These results indicate consistency, meaning that if the developed needs questionnaire is repeated, it will get the same results. and this value is greater than $r_{\text {table }}$ for $\mathrm{df}=113$, which is 0.1832 because $\mathrm{r}_{\text {count }}>\mathrm{r}_{\text {table }}$ then it is included in the reliable category. These results indicate consistency, meaning that if the developed needs questionnaire is repeated, it will get the same results.

Based on all the data obtained from the questionnaire on the needs of Palembang Poltekbang students for an effective online learning system, it can be concluded that the online learning system based on MOOCs is very suitable to be applied at Poltekbang Palembang because what students need can be realized through an online learning system based on MOOCs. The results obtained are supported by Busri et al. (2019), who obtained research results in online learning media MOOC Physics business. Power and energy materials can be applied as an effective learning tool. It is because MOOC media can be accessed anytime and anywhere. With MOOC, students and teachers can carry out the learning process without face to face.

\section{CONCLUSION}

Of all statements regarding the needs of Palembang Poltekbang students for effective online learning, almost all of them were answered, with the most significant percentage being in the answer choices strongly agree and agree. It proves that students need the points offered in each statement they fill in the needs questionnaire sheet. For further research, it can be done at different universities or the same university but with the research topic continuing the research that has been done.

\section{REFERENCES}

Argaheni, N. B. (2020). Sistematik Review: Dampak Perkuliahan Daring Saat Pandemi COVID-19 Terhadap Mahasiswa Indonesia. PLACENTUM: Jurnal Ilmiah Kesehatan Dan Aplikasinya, 8(2), 99. https://doi.org/10.20961/placentum.v8i2.43008

Busri, E., Zulirfan, Z., \& Fakhruddin, F. (2019). The Development of MOOC Media to Increase Recall Memory Skill on Physics at Vocational High School. Journal of Physics: Conference Series, 1(1), 1-4. https://doi.org/10.1088/1742-6596/1351/1/012017

Dewi, W. A. F. (2020). Dampak COVID-19 terhadap Implementasi Pembelajaran Daring di Sekolah Dasar. Edukatif : Jurnal Ilmu Pendidikan, 2(1), 55-61. https://doi.org/10.31004/edukatif.v2i1.89 
Dyah Purnama Sari, \& Sutapa, P. (2020). Efektifitas Pembelajaran Jarak Jauh dengan Daring Selama Pandemi COVID-19 Mata Pelajaran Pendidikan Jasmani Olahraga dan Kesehatan (PJOK). Pediatric Critical Care Medicine, 19-29.

Emigawaty. (2017). Perancangan arsitektur dan purwarupa model pembelajaran massive open online course (MOOCS) di perguruan tinggi menggunakan layanan mobile. Jurnal Ilmiah DASI, 18(1), 25-30.

Fathurrochman, I., Danim, S., Anwar AB, S., \& Kurniah, N. (2021). The School Principals' Role in Education Management at the Regional Level: An Analysis of Educational Policy in the Industrial Revolution 4.0. Advances in Social Science, Education and Humanities Research, 532, 237-242.

Hardi, R., Gunawan, \& Sumardi. (2018). Pendekatan Baru Teknologi Mooc Sebagai Media Pembelajaran Pada Matakuliah Pemrograman. SNITT- Politeknik Negeri Balikpapan 2018, $317-323$.

Husna, J. (2019). Implementasi MOOCs di Pendidikan Ilmu Perpustakaan dan Informasi (Sebuah Peluang dan Tantangan di Indonesia). Anuva: Jurnal Kajian Budaya, Perpustakaan, Dan Informasi, 3(3), 247-256.

Ismail, M. E., Hashim, S., Ismail, I. M., Ismail, A., Daud, K. A. M., \& Khairudin, M. (2018). Penggunaan Massive Open Online Course (Mooc) Dalam Kalangan Pelajar Vokasional. Journal of Nusantara Studies, 3(1), 30-41.

Jayul, A., \& Irwanto, E. (2020). Model Pembelajaran Daring Sebagai Alternatif Proses Kegiatan Belajar Pendidikan Jasmani di Tengah Pandemi Covid-19 Achmad. Jurnal Pendidikan Kesehatan Rekreasi, 6(2), 190-199.

Nastiti, F., \& Abdu, A. (2020). Kajian: Kesiapan Pendidikan Indonesia Menghadapi Era Society 5.o. Edcomtech Jurnal Kajian Teknologi Pendidikan, 5(1), 61-66. https://doi.org/10.17977/umo39v5i12020po61

Praherdhiono, H., Adi, E. P., \& Prihatmoko, Y. (2018). Konstruksi Demokrasi Belajar Berbasis Kehidupan Pada Implementasi Lms Dan MOOC. Edcomtech, 3(1), 21-28.

Prasetyo, H., \& Sutopo, W. (2018). Industri 4.o: Telaah Klasifikasi Aspek Dan Arah Perkembangan Riset. Jurnal Teknik Industri, 13(1), 17-26. https://doi.org/10.14710/jati.13.1.17-26

Putrawangsa, S., \& Hasanah, U. (2018). Integrasi Teknologi Digital Dalam Pembelajaran Di Era Industri 4.o Kajian dari Perspektif Pembelajaran Matematika. Jurnal Tatsqif, 16(1), 42-54. https://doi.org/10.20414/jtq.v16i1.203

Risdianto, E. (2019). Kepemimpinan Dalam Dunia Pendidikan Di Indonesia di Era Revolusi Industri 4.O. 1-12.

Risdianto, E., Yanto, M., Kristiawan, M., \& Gunawan, G. (2021). Respon Guru Pendidikan Anak Usia Dini terhadap MOOCs berbantuan Augmented Reality. Jurnal Obsesi: Jurnal Pendidikan Anak Usia Din, 5(2), 1487-1500. https://doi.org/10.31004/obsesi.v5i2.907

Sabri, I. (2019). Peran Pendidikan Seni Di Era Society 5 . o untuk Revolusi Industri 4.o. Prosiding Seminar Nasional Pascasarjana UNNES, 2(1), 342-347. https://proceeding.unnes.ac.id/index.php/snpasca/article/view/302

Wardina, U. V., Jalinus, N., \& Asnur, L. (2019). Kurikulum Pendidikan Vokasi Pada Era Revolusi Industri 4.o. Jurnal Pendidikan, 2O(1), 82-90. https://doi.org/10.33830/jp.v20i1.843.2019 